\title{
ANALISIS KEPATUHAN PRINSIP-PRINSIP SYARIAH TERHADAP KESEHATAN FINANSIAL DAN FRAUID PADA BANK UMUM SYARIAH
}

\author{
Marheni \\ STAIN Syaikh Abdurrahman Siddik Bangka Belitung
}

\begin{abstract}
This aim of study were to determine the effect of Islamic income on financial health of sharia banks; To know the effect of financing profit sharing on financial health of sharia banks; To determine the effect of Islamic income on the fraud of sharia banks; To know financing profit sharing on fraud of sharia banks and to determine the effect financial health on fraud of sharia banks. The population research were all sharia banks in Indonesia. Selected samples were 8 sharia banks. Analysis method used path analysis. The results showed that Islamic income had positive and significant effect on financial health, financing profit sharing had positive and significant effect on financial health. Islamic income had a negative and significant effect on fraud. Shared financing had a negative and significant effect on fraud. Financial health hada positive and significant effect on fraud.
\end{abstract}

Keywords : financial health, financing profit sharing , fraud, Islamic income and sharia banks

\section{Latar Belakang}

Perkembangan perbankan syariah di Indonesia semakin pesat setelah disahkannya Undang-undang No. 21 tahun 2008 tentang Perbankan Syariah. ${ }^{1}$ Undang-Undang ini diatur mengenai masalah kepatuhan syariah (syariah compliance) yang kewenangannya berada pada Majelis Ulama Indonesia (MUI) yang direpresentasikan melalui Dewan Pengawas Syariah (DPS) yang harus dibentuk pada masing-masing Bank Umum Syariah dan Unit Usaha Syariah.

\footnotetext{
${ }^{1}$ Jumansyah dan Ade Wirman Syafei. 2013. Analisis Penerapan Good Governance Business Syariah dan Pencapaian Maqashid Shariah Bank Syariah di Indonesia. Jurnal Al-Azhar Indonesia Seri Pranata Sosial, Vol. 2, No. 1.
} 
Beberapa Peraturan Bank Indonesia mengenai perbankan syariah antara lain Peraturan Bank Indonesia No.4/1/PBI/2002 tentang perubahan kegiatan usaha Bank Umum Konvensional menjadi Bank Umum berdasarkan prinsip syariah dan pembuatan kantor bank berdasarkan prinsip syariah oleh Bank Umum Konvensional. PBI No.6/24/PBI/2004 tentang bank umum yang melaksanakan kegiatan usaha berdasarkan prinsip syariah sebagaimana diubah dengan PBI No. 7/35/PBI/2005. PBI No. 7/46/PBI/2005 tentang akad penghimpunan dan penyaluran dana bagi bank yang melaksanakan kegiatan usaha berdasarkan prinsip syariah. PBI No.9/1/PBI/2007 tentang sistem penilaian tingkat kesehatan bank umum berdasarkan prinsip syariah. SE No.9/24/DPbS/2007, surat edaran tentang penilaian tingkat kesehatan bank umum berdasarkan prinsip syariah. PBI No. 9/19/PBI/2007 tentang pelaksanaan prinsip syariah dalam kegiatan penghimpunan dana dan penyaluran dana serta pelayanan jasa bank syariah. UU No.21 Tahun 2008 tentang perbankan syariah. PBI No.11/24/PBI/2009 tentang fasilitas pendanaan jangka pendek syariah bagi Bank Umum Syariah. PBI No. 11/31/PBI/2009 tentang uji kemampuan dan kepatutan (Fit And Proper Test) Bank Umum Syariah danUnit UsahaSyariah.

Perkembangan jumlah Bank Umum Syariah (BUS), Unit Usaha Syariah (UUS), dan Bank Pembiayaan Rakyat Syariah (BPRS) selama periode tahun 2008 jumlah Bank Umum Syariah dan Unit Usaha Syariah sampai dengan 2016 mengalami perubahan, namun demikian jumlah jaringan kantor meningkat. Meskipun dengan jumlah BUS sebanyak 12 bank maupun UUS sebanyak 22 bank, yang sama pelayanan masyarakat perbankan syariah akan menjadi semakin luas dengan bertambahnya jumlah kantor perbankan syariah dari jumlah bank maupun jumlah kantor baik Bank UmumSyariah (BUS), Unit Usaha Syariah (UUS), maupun Bank Pembiayaan Rakyat Syariah (BPRS). 
Tabel 1

Perkembangan Jumlah Bank dan Kantor Perbankan Syariah di Indonesia Tahun 2009 - Januari 2016

\begin{tabular}{lrrrrrrrr}
\hline Indikator & 2009 & 2010 & 2011 & 2012 & 2013 & 2014 & 2015 & $\begin{array}{c}\text { Jan } \\
2016\end{array}$ \\
\hline BUS & 6 & 11 & 11 & 11 & 11 & 12 & 12 & 12 \\
Jumlah & & & & & & & & \\
Kantor & 711 & 1.215 & 1.401 & 1.745 & 1.998 & 2.163 & 1.990 & 1.970 \\
UUS & 25 & 23 & 24 & 24 & 23 & 22 & 22 & 22 \\
Jumlah & & & & & & & & \\
Kantor & 287 & 262 & 336 & 517 & 590 & 320 & 311 & 312 \\
BPRS & 138 & 150 & 155 & 158 & 163 & 163 & 163 & 163 \\
Jumlah & & & & & & & & \\
Kantor & 225 & 286 & 364 & 401 & 402 & 439 & 446 & 449 \\
\hline
\end{tabular}

Sumber: Statistik Perbankan Syariah, Januari 2016.

Tabel 1 menunjukkan perkembangan perbankan syariah dimana pada tahun 2009 terdapat 6 (enam) Bank Umum Syariah di Indonesia yang kemudian naik dua kali lipat menjadi 12 (dua belas) dalam kurun waktu 6 (enam) tahun. Perkembangan ini dikuti dengan bertambah pula jumlah kantor yang pada tahun 2009 berjumlah 711 kantor menjadi 1.970 kantor. Begitu pula UUS dan BPRS yang terus berkembang di Indonesia.

Perkembangan bank umum syariah yang ditandai dengan peningkatan kesehatan finansial. Kesehatan suatu bank merupakan kepentingan semua pihak yang terkait, baik pemilik, pengelola bank, masyarakat pengguna jasa bank dan Bank Indonesia (BI) selaku otoritas pengawasan bank. Tingkat kesehatan bank adalah penilaian atas suatu kondisi laporan keuangan bank pada periode dan saat tertentu sesuai dengan standar BI. Peraturan Bank Indonesia No.9/1/PBI/2007 tentang sistem penilaian tingkat kesehatan bank umum berdasarkan prinsip syariah.

Pengelolaan bank syariah harus mengacu kepada standard dan pedoman tata kelola yang sesuai dengan prinsip-prinsip syariah. Bank Indonesia (2009) 
mendorong agar pengelolaan bank syariah di Indonesia mengacu kepada prinsip-prinsip Good Governance Bisnis Syariah (GGBS). Bank Indonesia (2009) mengharapkan dengan pengelolaan bank syariah berdasarkan kepada prinsipprinsip GGBS maka akan mendorong terwujudnya bank syariah yang sehat secara finansial namun juga bank syariah yang patuh terhadap prinisp-prinsip syariah dalam seluruh lini operasionalnya. ${ }^{2}$

Adanya permasalahan pada perbankan syariah, dimana kinerja bank syariah dari tahun 2009-2014 belum mengalami kesehatan finansial optimal, sehingga perlu dilakukan penelitian lebih lanjut tentang faktor-faktor apa saja yang dapat mempengaruhi tingkat kesehatan finansial bank dan juga rekomendasi yang tepat agar bank syariah dapat mencapai kesehatan finansial yang optimal. Berdasarkan fenomena tersebut secara teoritis penilaian tingkat kesehatan bank umum syariah yang diatur dalam PBI No.9/1/PBI/2007 menyatakan bahwa, tingkat kesehatan bank adalah hasil penilaian kualitatif maupun kuantitatif atas berbagai faktor yang berpengaruh terhadap kondisi atau kinerja suatu bank.

Berdasarkan kasus, faktor-faktor yang mempengaruhi kinerja keuangan menurut Hameed et. al (2004) 3 terdiri dari tiga faktor yaitu indikator kepatuhan syariah (Shariah Compliance), indikator tata kelola perusahaan (Corporate Governance) dan indikator sosial (social/environment). Asrori (2014) melakukan penelitian terkait implementasi Islamic Corporate Governance dan pengaruhnya terhadap kinerja bank syariah yang diukur dengan rasio-rasio keuangan Islam syariah conformity dan rasio-rasio keuangan konvensional profitability. ${ }^{4}$

Beberapa faktor yang dijelaskan diatas maka penelitian ini mengambil

\footnotetext{
${ }^{2}$ Op.Cit. Jumansyah dan Ade Wirman Syafei. hal. 3

${ }^{3}$ Hameed, S., A. Wirman, B. Alrazi, M. Nazli dan S. Pramono.2004. Alternative Disclosure and Performance Measures for Islamic Bank. www.iium.edu.my diakses tanggal 4 Mei 2017

${ }^{4}$ Asrori. 2011. Pengungkapan Syari'ah Compliance dan Kepatuhan Bank Syariah Terhadap Prinsip Syariah. Jurnal Dinamika Akuntansi, Vol. 3, No. 1, Maret, pp. 1-7.
} 
faktor kepatuhan syariah dan Islamic corporate governance. Kepatuhan syariah merupakan manifestasi pemenuhan seluruh prinsip syariah dalam lembaga yang memiliki wujud karakteristik, integritas dan kredibilitas dibank syariah.Dimana budaya kepatuhan tersebut adalah nilai, perilaku dan tindakan yang mendukung terciptanya kepatuhan bank syariah terhadap seluruh ketentuan Bank Indonesia 5 .

Ada beberapa kasus dimana nasabah melaporkan bank syariah, seperti yang dialami oleh BRI Syariah dan Bank Mega Syariah, keduanya terkena kasus terkait gadai emas. Kasus ini muncul atas gugatan nasabah BRI Syariah dan Bank Mega Syariah yang merasa dirugikan terkait gadai emas yang ada pada BRI Syariah dan Bank Mega Syariah ${ }^{6}$. Tidak hanya di Indonesia,beberapa kasus pada bank syariah juga pernah terjadi di negara lain, seperti yang terjadi pada Dubai Islamic Bank yang kehilangan sekitar US\$ 300 miliar akibat laporan keuangan yang tidak tepat dan pada Islamic Bank of South Africa yang bangkrut pada tahun 1997 dengan hutang antara R50 hingga R70 juta yang disebabkan oleh manajemen yang buruk serta sistem akuntansi dan manajemen yang tidak tepat7. Dari adanya kasus-kasus tersebut membuktikan bahwa tidak ada jaminan bahwa lembaga syariah terutama bank yang berbasis syariah bebas dari tindakan fraud.

Fraud di dalam organisasi dapat dilakukan oleh berbagai tingkatan mulai dari level bawah, pihak manajemen sampai pemilik ${ }^{8}$. Untuk itu sebagai entitas

${ }^{5}$ Ibid. hal. 4

${ }^{6}$ Wijaya, Angga Sukma. 2012. Kasus Gadai Emas Perburuk Citra Produk Syariah. https://m.tempo.co/read/news/2012/10/04/087433724/kasus-gadaiemas-perburuk-citra-produk-syariah. Diakses tanggal 1 Mei 2017.

${ }^{7}$ Rini, R. 2014. The effect of audit committee role and sharia supervisory board role on financial reporting quality at Islamic banks in Indonesia. Journal of Economics, Business \& Accountancy Ventura, 17 (1), pp. 145-156.

${ }^{8}$ Najib dan Rini. 2016. Sharia Compliance, Islamic Corporate Governance dan Fraud Pada Bank Syariah. Jurnal Akuntansi dan Keuangan Islam. Vol. 4, No. 2. 
yang memiliki karakter khusus, bisnis keuangan syariah memiliki risiko yang tinggi dalam pengelolaannya, sehingga dibutuhkan prinsip kehati-hatian para pelakunya dalam aspek kepatuhan syariah (Sharia Compliance) sebagai upaya pencegahan kemungkinan risiko terjadinya fraud ${ }^{9}$.

Penelitian ini menggunakan indikator kepatuhan prinsip syariah yaitu indikator dari rasio pendapatan Islam, rasio pembiayaan bagi hasil, dan rasio investasi Islam. Pendapatan Islam adalah pendapatan yang berasal dari investasi yang sesuai dengan prinsip-prinsip syariah, pembiayaan bagi hasil merupakan pembiayaan berdasarkan prinsip syariah adalah penyediaan uang atau tagihan yang dipersamakan dengan berdasarkan persetujuan atau kesepakatan antara bank dengan pihak lain, dan investasi Islam merupakan aktivitas penempatan dana sesuai dengan prinsip-prinsip syariah yang dalam kegiatan penghimpunan dana, pembiayaan dan kegiatan jasa BPRS lainnya.

Kepatuhan prinsip syariah digunakan sebagai variabel pada penelitian ini karena para nasabah meragukan konsistensi penerapan prinsip syariah maka para pengelola bank umum syariah harus benar-benar menerapkan prinsipprinsip syariah yang dikeluarkan Bank Indonesia tanpa adanya keresahan terhadap resiko kelangsungan usaha dan kesehatan finansialnya.

Penelitian terkait tata kelola perusahaan secara Islam dan kepatuhan pada prinsip-prinsip syariah dilakukan karena pertama, kepatuhan syariah dan tata kelola perusahaan secara Islam dapat dikatakan sebagai unsur yang sangat penting di dalam perbankan syariah, lemahnya tata kelola perusahaan serta rendahnya kepatuhan syariah dapat mempengaruhi kinerja serta memberikan peluang untuk terjadinya kecurangan di dalam bank syariah. Kedua, peneliti ingin mengetahui apakah prinsip-prinsip syariah serta tata kelola peusahaan secara Islam yang diterapkan dalam perbankan syariah di Indonesia memiliki pengaruh terhadap tindak kecurangan yang terjadi didalam lembaga tersebut.

${ }^{9}$ Ibid. hal. 3 
Ketiga, sampai dengan tahap penyelesaian penelitian ini, peneliti belum menemukan penelitian yang secara spesifik menguji pengaruh kepatuhan syariah dan tata kelola perusahaan terhadap kecurangan bank syariah.

Berdasarkan latar belakang diatas, tujuan dalam penelitian ini adalah sebagai berikut:

a. Untuk mengetahui pengaruh pendapatan Islam terhadap kesehatan finansial bank syariah.

b. Untuk mengetahui pengaruh pembiayaan bagi hasil terhadap kesehatan finansial bank syariah.

c. Untuk mengetahui pengaruh pendapatan Islam terhadap fraud bank syariah.

d. Untuk mengetahui pembiayaan bagi hasil terhadap fraud bank syariah.

e. Untuk mengetahui pengaruh kesehatan finansial bank syariah terhadap fraud bank syariah.

\section{Literature Review and Hypotesis}

\section{Agency Theory}

Pemahaman good corporate governance menggunakandasar perspektif hubungan keagenan. Hubungan keagenan adalah sebuah kontrak antara manajer (agent) dengan investor (principal). Terjadinya konflik kepentingan antara pemilik dan agen karena kemungkinan agen bertindak tidak sesuai dengan kepentingan principal, sehingga memicu biaya keagenan (agency cost) ${ }^{10}$.

Teori keagenan pada dasarnya merupakan teori yang muncul karena adanya konflik kepentingan antara prinsipal dan agen. Teori ini mengasumsikan bahwa masing-masing individu semata-mata termotivasi oleh kepentingan dirinya sendiri sehingga menimbulkan konflik kepentingan antara prinsipal dan agen. Prinsipal mengontrak agen untuk melakukan pengelolaan sumber daya dalam perusahaan dan berkewajiban untuk

\footnotetext{
${ }^{10}$ Jensen, M. C and Meckling, W.H. 1976. Theory of the Firm: Managerial Behavior, Agency Costs and Ownership Structure. Journal of Financial Economics, Vol. 3, No. 4, pp. 305-360
} 
memberikan imbalan kepada agen sedangkan agen berkewajiban melakukan pengelolaan sumber daya yang dimiliki oleh perusahaan dan bertanggungj awab atas tugas yang dibebankan kepadanya. Hubungan prinsipal dan agen terjadi apabila tindakan yang dilakukan seseorang memiliki dampak pada oranglain atau ketika seseorang sangat tergantung pada tindakan orang lain. Pengaruh atau ketergantungan ini diwujudkan dalam kesepakatankesepakatan dalam struktur institusional pada berbagai tingkatan, seperti norma perilaku dan konsep kontrak antara keduanya11.

Teori keagenan dilandasi oleh 3 (tiga) asumsi yaitu (a) asumsi tentang sifat manusia; (b) asumsi tentang keorganisasian dan (c) asumsi tentang informasi. Asumsi tentang sifat manusia menekankan bahwa manusia memiliki sifat mementingkan diri sendiri (self interest) memiliki keterbatasan rasionalitas (bounded rationality) dan tidak menyukai resiko (risk aversion). Asumsi keorganisasian menekankan adanya konflik antar anggota organisasi, efisiensi sebagai kriteria produktivitas. Asimetri informasi (asimmetric information). Merupakan informasi yang tidak seimbang karena perbedaan distribusi informasi antara prinsipal dan agen.

Berdasarkan teori ini, terjadi pemisahan antara pemilik (principal) dan pengelola perusahaan (agent) sehingga menimbulkan agency problem. Selanjutnya pemisahan pemilik dan pengelola juga menimbulkan asimetri informasi yaitu suatu keadaan dimana agent memiliki akses informasi yang tidak dimiliki oleh pihak principal. Asimetri informasi muncul ketika agent lebih banyak mengenal (mengetahui) informasi internal dan prospek masa yang akan datang, dibandingkan pengetahuan tentang informasi yang di kenal/diketahui oleh principal dan stakeholder lainnya ${ }^{12}$. Berdasarkan asumsi sifat dasar manusia, setiap manusia memiliki kecenderungan untuk bertindak

\footnotetext{
${ }^{11}$ Lane, J. E. 2000. The Public Sector - Concepts, Models and Approaches. London: SAGE Publicationshal. 121

${ }^{12}$ Anugerah, R. 2014. Peranan Good Corporate Governance Dalam Pencegahan Fraud. Jurnal Akuntansi, 3 (1), pp. 101-113.
} 
dengan mengutamakan kepentingan pribadinya.

Perbedaan kepentingan menyebabkan agen menyalahgunakan kewajibannya dalam penyampaian informasi kepada principal dengan cara memberikan atau menahan informasi yang diminta principal bila menguntungkan bagi agen. Untuk mengatasi hal tersebut, diperlukan penerapan Good Corporate Governance beserta prinsip-prinsip dan mekanismenya untuk dapat memastikan hak dan hubungan diantara seluruh stakeholder ini terjamin.

\section{Stewardship Theory}

Teori Stewardship diperkenalkan sebagai teori yang berdasarkan tingkah laku, prilaku manusia (behavior), pola manusia (model of man), mekanisme psikologis (motivasi, identifikasi dan kekuasaan) dalam sebuah organisasi yang mempraktikkan kepemimpinan sebagai aspek yang memainkan peranan penting bagi sebuah pencapaian tujuan. Teori ini berakar dari ilmu psikologi dan sosiologi yang mengarah pada sikap melayani (Steward) ${ }^{13}$.

Stewardship (suatu sikap melayani), merupakan suatu pandangan baru tentang mengelola dan menjalankan organisasi, suatu pergeseran pendekatan pada konsep kepemimpinan dan manajemen yang ada sekarang dari konsep mengendalikan (control) dan mengarahkan, kearah konsep peraturan, kemitraan, dan kepemilikan secara bersama oleh anggota/ tim dalam organisasi, yang merasa organisasi menjadi suatu miliknya ataupun satu kesatuan yang tidak dapat dipisahkan dari diri sendiri ${ }^{14}$.

Teori stewardship didefinisikan sebagai situasi dimana para steward (pengelola) tidak mempunyai kepentingan pribadi tetapi lebih mementingkan

\footnotetext{
${ }^{13}$ Ibid. hal. 104

${ }^{14}$ Arfan, Ikhsan dan Herkulanus Bambang Suprasto. 2008. Teori Akuntansi dan multi Paradigma, Edisi Satu. Jakarta: Graha Ilmu.
} 
kepentingan principal (pemilik)15. Teori stewardship ini mengasumsikan hubungan yang kuat antara kesuksesan organisasi dengan kinerja perusahaan, sehingga profitabilitas akan maksimal dan tujuan sesuai dengan harapan pemilik. Karena steward lebih melihat pada usaha untuk mencapai tujuan organisasi dan bukan pada tujuan individu. Stewardship theory adalah sikap melayani, dimana manajemen mempunyai sikap melayani para stakeholdernya. Artinya ketika manajemen melaksanakan kegiatan operasional perusahaan manajemen juga memberikan pelayanan di bidang ekonomi yang sesuai dengan prinsip syariah. Teori stewardship dalam penelitian ini digunakan untuk menjelaskan hubungan variabel kepatuhan prinsip syariah dengan indikator pendapatan Islam, investasi Islam, dan pembiayaan bagi hasil sebagai variabel independen dengan variabel kesehatan finansial sebagai variabel dependen.

Implikasi teori stewardship dalam penelitian ini adalah ketika bank umum syariah mengelola kegiatan operasionalnya sesuai dengan prinsip syariah diharapkan pendapatan Islam, investasi Islam tinggi atau lebih banyak memberikan pembiayaan dalam bagi hasil maka kesehatan finansialnya meningkat. Tanpa adanya kepatuhan terhadap prinsip syariah masyarakat akan kehilangan keistimewaan yang mereka cari dalam layanan perbankan syariah sehingga akan berpengaruh pada keputusan mereka untuk memilih atau terus melanjutkan pemanfaatan jasa yang diberikan oleh bank syariah. Jadi kepatuhan syariah merupakan salah satu cara untuk menjaga kepercayaan dari masyarakat

\section{Teori Legitimasi}

Teori legitimasi (Legitimacy Theory) sebagai suatu kondisi yang ada ketika suatu sistem nilai perusahaan yang sejalan dengan sistem nilai yang berlaku. Perusahaan menjalankan kegiatan operasionalnya sesuai dengan norma dan

\footnotetext{
${ }^{15}$ Ibid. hal. 4
} 
aturan yang berlaku. Menurut Suchman (1995)16, menyebutkan:

"Legitimacy is a generalized perceptionor assumption that the actions of an entity are desirable, proper, or appropriate within some socially constructed system of norms, values, beliefs, anddefinitions"(Suchman,1995 dalam In'airat).

Legitimasi dapat dianggap sebagai menyamakan persepsi atau asumsi bahwa tindakan yang dilakukan oleh suatu entitas merupakan tindakan yang diinginkan, pantas ataupun sesuai dengan sistem norma, nilai, kepercayaan dan definisi yang dikembangkan secara sosial. Legitimasi dianggap penting bagi perusahaan dikarenakan legitimasi masyarakat kepada perusahaan menjadi faktor yang strategis bagi perkembangan perusahaan kedepan.

Implikasi teori legitimasi dalam penelitian ini adalah eksistensi Dewan Direksi dan Dewan Pengawas Syariah, dimana Dewan Direksi dan Dewan Pengawas Syariah menjalankan tugas dan tanggung jawabnya sesuai dengan prinsip syariah dalam pengelolaan perbankan syariah dan sesuai dengan Undang-Undang Nomor 21 tahun 2008 tentang Perbankan Syariah pasal 12 menyebutkan bahwa yang dimaksud dengan prinsip syariah yakni prinsip hukum Islam berdasarkan fatwa yang dikeluarkan oleh lembaga yang memiliki kewenangan dalam penetapan fatwa di bidang syariah. Asasnya adalah demokrasi ekonomi dengan prinsip kehati-hatian (pasal 2) sedangkan pasal 3 menyebutkan bahwa tujuan perbankan syariah menunjang pelaksanaan pembangunan nasional dalam rangka meningkatkan keadilan, kebersamaan, dan pemerataan kesejahteraan rakyat.

Tujuan perbankan syariah ini dapat terwujud jika para manajemen menjalankan kegiatan operasionalnya sesuai dengan norma dan aturan yang berlaku dan dapat menjalankan fungsinya secara baik, termasuk fungsi dari Dewan Direksi dan Dewan Pengawas Syariah. Dewan Direksi/ Direktur bertanggungjawab penuh atas pelaksanaan pengelolaan BUS/ UUS

${ }^{16}$ In'airat, M. 2015. The Role of Corporate Governance in Fraud Reduction- A Perception Study in the Saudi Arabia Business Environment. Journal of Accounting and Finance, 15 (2), pp. 119. 
berdasarkan prinsip kehati-hatian dan prinsip syariah dan berkewajiban mengelola BUS/ UUS sesuai dengan kewenangan dan tanggung jawabnya sedangkan Dewan Pengawas Syariah bertugas memberikan nasehat.

\section{Pengaruh Pendapatan Islam terhadap Kesehatan Finansial dan Fraud}

Pendapatan Islam adalah pendapatan yang berasal dari investasi yang sesuai dengan prinsip-prinsip syariah. Menurut Hammed et.al. (2004) ${ }^{17}$ prinsipprinsip syariah melarang transaksi yang melibatkan riba, gharar dan perjudian tetapi mendorong transaksi yang halal. Bank syariah hanya menerima pendapatan dari sumber yang halal. Rasio Pendapatan Islam menunjukkan presentase dari seberapa banyak pendapatan halal yang didapatkan dibandingkan dengan total pendapatan meliputi total pendapatan Islam ditambah pendapatan non halal.

Sejalan dengan teori Stewardship, pendapatan Islam yang sesuai dengan prinsip syariah dalam pengelolaan operasional dan usaha perbankan syariah dapat menghilangkan keraguan masyarakat akan kehilangan keistimewaan yang mereka cari dalam layanan perbankan syariah sehingga akan berpengaruh pada keputusan mereka untuk memilih atau terus melanjutkan pemanfaatan jasa yang diberikan oleh bank syariah. Apabila pendapatan Islam meningkat maka kesehatan finansialnya meningkat karena pendapatan Islam yang sesuai prinsip syariah merupakan salah satu cara untuk menjaga kepercayaan dari masyarakat untuk tetap memilih Bank Umum Syariah.

Penelitian menunjukan hubungan positif antara rasio pendapatan Islam dengan kesehatan finansial antara lain Asrori (2014)18, Hameed et.al. (2004) ${ }^{19}$

\footnotetext{
${ }^{17}$ Loc. Cit. Hammed

${ }^{18}$ Op.cit. Asrori

${ }^{19}$ Op.cit. Hameed et.al.
} 
dan Kupusamy et. al. (2010) ${ }^{20}$ yang berhasil membuktikan pengaruh rasio pendapatan Islam terhadap kesehatan finansial dan fraud.

\section{Pengaruh Pembiayaan Bagi Hasil terhadap Kesehatan Finansial dan Fraud.}

Pembiayaan bagi hasil merupakan pembiayaan berdasarkan prinsip syariah. Pembiayaan berdasarkan prinsip syariah adalah penyediaan uang atau tagihan yang dipersamakan dengan berdasarkan persetujuan atau kesepakatan antara bank dengan pihak lain yang mewajibkan pihak yang dibiayai untuk mengembalikan uang atau tagihan tersebut setelah jangka waktu tertentu dengan imbalan atau bagi hasil. Menurut Undang-Undang Nomor 10 Tahun 1998. Pembiayaan bagi hasil pada perbankan syariah dilakukan melalui akad mudharabah dan musyarakah. Pembiayaan bagi hasil merupakan salah satu komponen penyusun aset pada perbankan syariah.

Sejalan dengan teori Stewardship, pembiayaan bagi hasil yang sesuai dengan prinsip syariah dalam pengelolaan operasional dan usaha perbankan syariah dapat menghilangkan keraguan masyarakat akan kehilangan keistimewaan

yang mereka cari dalam layanan perbankan syariah sehingga akan berpengaruh pada keputusan mereka untuk memilih atau terus melanjutkan pemanfaatan jasa yang diberikan oleh bank syariah. Apabila pembiayaan bagi hasil meningkat maka kesehatan finansialnya meningkat karena pembiayaan bagi hasil yang sesuai prinsip syariah merupakan salah satu cara untuk menjaga kepercayaan dari masyarakat untuk tetap memilih Bank Umum Syariah.

Penelitian menunjukan hubungan positif antara rasio pembiayaan bagi

\footnotetext{
${ }^{20}$ Kuppusamy, Mudiarasan, Ali Salma Saleh, and Ananda Samudhram. 2010. Measurement of Islamic Banks Performance using Shari'a Conformity and Profitability Model. International Association for Islamics Economics. Review of Islamic Economics. Vol. 13, No. 2, pp. 35-48.
} 
hasil dengan kesehatan finansial antara lain Falikhatun (2012)21, Asrori (2014)22, dan Kupusamy et.al. (2010) ${ }^{23}$ yang berhasil membuktikan pengaruh rasio pembiayaan bagi hasil terhadap kesehatan finansial.

\section{Pengaruh Kesehatan Finansial terhadap Fraud Bank Syariah}

Adanya pelanggaran batas maksimum pemberian kredit, rendahnya praktek manajemen resiko, tidak adanya transparansi terhadap informasi keuangan kepada nasabah, dan adanya dominasi para pemegang saham dalam mengatur operasional perbankan menyebabkan rapuhnya industri perbankan nasional ${ }^{24}$. Oleh sebab itu dengan kesehatan finansial menerapkan tata kelola perusahaan dengan baik apalagi memiliki nilai tambah dengan berlandaskan prinsip-prinsip Islam, memberikan indikasi dan kesan kepada masyarakat bahwa lembaga syariah terutama bank terhindar dari praktik kecurangan, walaupun kecurangan sendiri dapat terjadi dimana saja.

\section{Hipotesis Penelitian}

Berdasarkan hasil teori dan empiris, maka hipotesis penelitian ini:

H1 : Pendapatan Islam berpengaruh secara positif terhadap kesehatan finansial bank syariah.

H2 : Pembiayaan bagi hasil berpengaruh secara positif terhadap kesehatan finansial bank syariah.

H3 : Pendapatan Islam berpengaruh secara positif terhadap fraud bank syariah.

H4 : Pembiayaan bagi hasil berpengaruh secara positif terhadap fraud bank syariah.

H5: Kesehatan finansial bank syariah berpengaruh secara positif terhadap fraud

${ }^{21}$ Falikhatun. 2012. Bank Syariah Di Indonesia: Ketaatan Pada Prinsip Syariah dan Kesehatan Finansial, Vol.1 No. 1, Hal. 245-254.

${ }^{22}$ Op.cit. Kuppusamy, Mudiarasan, Ali Salma Saleh, and Ananda Samudhram

${ }^{23}$ Ibid. Hal. 54

${ }^{24}$ Maradita, A. 2014. Karakteristik Good Corporate Governance pada Bank Syariah dan Bank konvensional. Yuridika, 29 (2). 
bank syariah bank syariah.

\section{METHODS}

Jenis penelitian ini adalah explanatory research yaitu penelitian yang menjelaskan hubungan suatu variabel dengan variabel lain dan menguji keterkaitan antara beberapa variabel melalui pengujian hipotesis. Data yang digunakan adalah data sekunder yang berasal dari laporan tahunan berupa laporan keuangantahunan dan laporan pelaksanaan Good Corporate Governance Bank Umum Syariah selama tahun 2011 sampai dengan tahun 2015.

Populasi dalam penelitian ini adalah seluruh Bank Umum Syariah yang ada di Indonesia. Berdasarkan data Statistik Perbankan Syariah per Januari 2015 jumlah Bank Umum Syariah (BUS) adalah sejumlah 12 BUS. Waktu pengamatan penelitian yaitu dari tahun 2011 sampai dengan tahun 2012. Pemilihan tahun ini didasarkan pada fakta bahwa mayoritas BUS di Indonesia baru berdiri pada tahun 2011 dan didasarkan pula pada Surat Edaran Bank Indonesia No. 12/33/DPbS tanggal 30 April 2012 mengenai Pelaksanaan Good Corporate Governance untuk BUS yang berlaku pada tahun 2011. Berikut ini disajikan daftar Bank Umum Syariah dan Unit Usaha Syariah yang ada di Indonesia: 
Tabel 2

Populasi Bank Syariah

\begin{tabular}{cl}
\hline No & \multicolumn{1}{c}{ Nama Bank } \\
\hline 1 & PT. Bank Syariah Mandiri \\
2 & PT. Bank Syariah Muamalat Indonesia \\
3 & PT. Bank Syariah BNI \\
4 & PT. Bank Syariah BRI \\
5 & PT. Bank Syariah Mega Indonesia \\
6 & PT. Bank Jabar dan Banten \\
7 & PT. Bank Panin Syariah \\
8 & PT. Bank Syariah Bukopin \\
9 & PT. Bank Victoria Syariah \\
10 & PT. BCA Syariah \\
11 & PT. Maybank Indonesia Syariah \\
12 & PT. Bank Tabungan Pensiunan Nasional (BTPN) Syariah \\
\hline
\end{tabular}

Sumber: Bank Indonesia, Tahun 2015

Sampel merupakan bagian dari populasi yang karakteristiknya ingin diteliti dan dapat mewakili keseluruhan populasi. Teknik pengambilan sampel yang digunakan adalah purposive sampling, yaitu pemilihan sampel secara tidak acak yang mempunyai tujuan atau target tertentu, hanya data yang memenuhi kriteria yang akan dijadikan sampel. Jadi hanya data yang memenuhi kriteria berikut yang dapat dijadikan sampel:

1. Bank Umum Syariah yang tercatat dalam Bank Indonesia tahun 2011-2015.

2. Bank Umum Syariah yang memiliki laporan tahunan (annual report) tahun 2011-2015.

Berdasarkan kriteria maka sampel penelitian adalah sebagai berikut: 
Tabel 3

\section{Daftar Sampel Penelitian}

\begin{tabular}{|c|c|c|}
\hline No & Nama Bank & Webs \\
\hline 1 & Bank Syariah Mandiri & www.banksyariahmandiri.co.id \\
\hline 2 & Bank MuamalatIndonesia & www.bankmuamalat.co.id \\
\hline 3 & BNISyariah & www.bnisyariah.co.id \\
\hline 4 & BRISyariah & www.brisyariah.co.id \\
\hline 5 & Bank MegaSyariah & www.megasyariah.co.id \\
\hline 6 & Bnak Syariah Bukopin & www.syariahbukopin.co.id \\
\hline 7 & Bank Panin Syariah & www.paninbanksyariah.co.id \\
\hline 8 & BCA Syariah & www.bcasyariah.co.id \\
\hline
\end{tabular}

Sumber: Data Sekunder yang diolah, 2015.

Variabel independen dalam penelitian ini antara lain (1) Pendapatan Islam adalah pendapatan yang berasal dari investasi yang sesuai dengan prinsipprinsip syariah. Pendapatan Islam menunjukkan presentase dari seberapa banyak pendapatan halal yang didapatkan dibandingkan dengan total pendapatan meliputi total pendapatan Islam ditambah pendapatan non halal. (2) Pembiayaan bagi hasil, yang merupakan pembiayaan berdasarkan prinsip syrariah. Untuk menghitung bagi hasil dari pembiayaan yang dilakukan bank syariah meliputi mudharabah dan musyarakah.

Variabel interviening dalam penelitian ini adalah kesehatan finansial Bank Umum Syariah yang diukur dengan indikator-indikator yaitu faktor pemodalan yang diproksikan dengan Capital Adaquacy Ratio (CAR), kualitas aset yang diproksikan dengan Pembiayaan Non Performing (NPF), faktor rentabilitas yang diproksikan dengan Rasio Efisiensi Kegiatan Operasional (REO), dan faktor likuiditas yang diproksikan dengan Short Term Mismacht (STM). ${ }^{25}$ Perhitungan angka kesehatan finansial setelah NPF, REO, dan STM ditemukan angkanya melalui rumus yang telah dijelaskan diatas, langkah

${ }^{25}$ Setiawan, Azis Budi. 2009. Kesehatan Finansial dan Kinerja Sosial Bank Umum Syariah di Indonesia. Seminar Ilmiah: Kerjasama Magister Sains Keuangan: Universitas Paramadhina, Ikatan Ahli Ekonomi Islam (IAEI) Pusat, dan Masyarakat Ekonomi Syariah (MES). 
selanjutnya adalah menentukan peringkat untuk menentukan peringkat untuk mengetahui angka kredit yang akan diberikan seperti Tabel 4 sebagai berikut:

Tabel 4

PeringkatBerdasarkanAngka Kredit

\begin{tabular}{cc}
\hline Peringkat & Angka Kredit \\
\hline 1 & 100 \\
2 & 80 \\
3 & 60 \\
4 & 40 \\
5 & 20 \\
\hline
\end{tabular}

Sumber: Setiawan (2009)26

Setelah menemukan peringkat angka kredit, selanjutnya melakukan pembobotan sesuai dengan angka kredit yang telah diberikan kepada masingmasing sempel. Berikutnya untuk menghasilkan nilai yang sudah dibobot maka dilakukan perkalian antara angka kredit dengan bobotnya. Sedangkan untuk menentukan predikat kesehatan finansial adalah mengikuti ketentuan yaitu: Sehat memiliki nilai bobot 81 s/d 100, Cukup Sehat memiliki nilai bobot 66 s/d $<81$, Kurang Sehat memiliki nilai bobot 51 s/d < 66 dan Tidak Sehat memiliki nilai bobot $0 \mathrm{~s} / \mathrm{d}<5$.

Sedangkan variabel dependen adalah fraud yang diukur dengan melihat jumlah internal fraud yang terjadi di bank syariah yang diungkapkan di dalam laporan tahunan pelaksanaan GCG masing- masing bank syariah. Jumlah internal fraud digunakan sebab dalam penelitian ini memfokuskan pada fraud yang terjadi dalam hubungan kerja (occupational fraud) atau yang disebut juga internal fraud.

Metode analisis data menggunakan analisis jalur (Path Analysis) adalah analisis untuk mengetahui besarnya sumbangan pengaruh setiap variabel $X$

\footnotetext{
${ }^{26}$ Sudiyatno, Banmbang. 2013. Faktor-Faktor yang Mempengaruhi Kinerja Bank (Studi Empiris pada Industri Perbankan Di Bursa Efek Indonesia). Jurnal Bisnis dan Ekonomi (JBE),Vol. 20, No. 1, pp.25-39.
} 
terhadap $\mathrm{Y}$ yang menggunakan regresi dengan variabel di bakukan (standardize).

\section{HASIL PENELITIAN}

Berdasarkan hasil koefisien jalur maka dapat dibuat persamaan berikut:

$$
\begin{aligned}
& Z=0,124+0,083 X_{1}+0,437 X_{2}+e \\
& Y=0,159-0,106 X_{1}-0,416 X_{2}-0,160 Z+e
\end{aligned}
$$

Berdasarkan persamaan tersebut maka dapat dijelaskan sebagai berikut:

\section{Pengaruh Variabel Pendapatan Islam $\left(X_{1}\right)$ terhadap Kesehatan financial} (Z)

Berdasarkan analisis jalur dapat dilihat untuk pengujian variabel pendapatan Islam terhadap kesehatan finansial diperoleh nilai beta $(\beta)$ sebesar 0,083 dengan $\rho$-value sebesar 0,006. Karena nilai $\rho$-value lebih kecil daripada a $(0,006<0,05)$ maka $\mathrm{H}_{0}$ ditolak. Hal itu menunjukkan ada pengaruh signifikan Pendapatan Islam terhadap kesehatan finansial.

\section{Pengaruh Variabel Pembiayaan Bagi Hasil $\left(X_{2}\right)$ terhadap Kesehatan Finansial (Z)}

Berdasarkan analisis jalur dapat dilihat untuk pengujian variabel pembiayaan bagi hasil terhadap kesehatan finansial diperoleh nilai beta $(\beta)$ sebesar 0,437 dengan $\rho$-value sebesar 0,011. Karena nilai $\rho$-value lebih kecil daripada a $(0,011<0,05)$ maka $\mathrm{H}_{0}$ ditolak. Hal itu menunjukkan ada pengaruh signifikan pembiayaan bagi hasil terhadap kesehatan finansial.

\section{Pengaruh Variabel Pendapatan Islam $\left(\mathrm{X}_{1}\right)$ terhadap Fraud $(\mathrm{Y})$}

Berdasarkan analisis jalur dapat dilihat untuk pengujian variabel pendapatan Islam terhadap fraud diperoleh nilai beta $(\beta)$ sebesar -0,106 dengan $\rho$-value sebesar 0,036. Karena nilai $\rho$-value lebih kecil daripada a $(0,005<0,05)$ 
maka $\mathrm{H}_{0}$ ditolak. Dengan demikian ada pengaruh signifikan pendapatan Islam terhadap fraud.

\section{Pengaruh Variabel Pembiayaan bagi hasil $\left(\mathrm{X}_{2}\right)$ terhadap Fraud $(\mathrm{Y})$}

Berdasarkan Analisis jalur dapat dilihat untuk pengujian variabel Pembiayaan bagi hasil terhadap Fraud diperoleh nilai beta $(\beta)$ sebesar -0,416 dengan $\rho$-value sebesar 0,016. Karena nilai $\rho$-value lebih kecil daripada a $(0,016<$ $0,05)$ maka $\mathrm{H}_{0}$ ditolak. Dengan demikian ada pengaruh signifikan pembiayaan bagi hasil terhadap fraud.

\section{Pengaruh Variabel Kesehatan Finansial (Z) terhadap Fraud (Y)}

Berdasarkan analisis jalur dapat dilihat untuk pengujian variabel kesehatan financial terhadap fraud diperoleh nilai beta $(\beta)$ sebesar $-0,160$ dengan $\rho$-value sebesar 0,003. Karena nilai $\rho$-value lebih kecil daripada a $(0,003<0,05)$ maka $\mathrm{H}_{0}$ ditolak. Dengan demikian ada pengaruh signifikan kesehatan finansial terhadap fraud.

\section{PEMBAHASAN}

\section{Pengaruh Variabel Pendapatan Islam terhadap Kesehatan finansial}

Hasil analisis jalur dapat dilihat untuk pengujian variabel pendapatan Islam terhadap kesehatan finansial diperoleh nilai beta $(\beta)$ sebesar 0,083 dengan $\rho$-value sebesar 0,006. Karena nilai $\rho$-value lebih kecil daripada a $(0,006<0,05)$ maka $\mathrm{H}_{0}$ ditolak. Hal itu menunjukkan ada pengaruh signifikan pendapatan Islam terhadap kesehatan finansial.

Hasil ini sesuai dengan teori Stewardship, pendapatan Islam yang sesuai dengan prinsip syariah dalam pengelolaan operasional dan usaha perbankan syariah dapat menghilangkan keraguan masyarakat akan kehilangan keistimewaan yang mereka cari dalam layanan perbankan syariah sehingga akan berpengaruh pada keputusan mereka untuk memilih atau terus 
melanjutkan pemanfaatan jasa yang diberikan oleh bank syariah. Apabila pendapatan Islam meningkat maka kesehatan finansialnya meningkat karena pendapatan Islam yang sesuai prinsip syariah merupakan salah satu cara untuk menjaga kepercayaan dari masyarakat untuk tetap memilih Bank Umum Syariah.

Hasil ini konsisten dengan Asrori (2014)27,dan Kupusamy et.al. (2010) ${ }^{28}$ yang berhasil membuktikan pengaruh rasio pendapatan Islam terhadap kesehatan finansial.

\section{Pengaruh Variabel Pembiayaan Bagi Hasil terhadap Kesehatan Finansial}

Prinsip syariah adalah aturan perjanjian berdasarkan hukum Islam antara bank dan pihak lain untuk penyimpanan dana dan atau pembiayaan kegiatan usaha, atau kegiatan lainnya yang dinyatakan sesuai dengan syariah, antara lain pembiayaan berdasarkan prinsip bagi hasil (mudharabah), pembiayaan berdasarkan prinsip penyertaan modal (musharakah), prinsip jual beli barang dengan memperoleh keuntungan (murabahah), atau pembiayaan barang modal berdasarkan prinsip sewa murni tanpa pilihan (ijarah), atau dengan adanya pilihan pemindahan kepemilikan atas barang yang disewa dari pihak bank oleh pihak lain (ijarah wa iqtina).

Hasil analisis jalur dapat dilihat untuk pengujian variabel pembiayaan bagi hasil terhadap kesehatan finansial diperoleh nilai beta $(\beta)$ sebesar 0,437 dengan $\rho$-value sebesar 0,011 . Karena nilai $\rho$-value lebih kecil daripada a $(0,011<$ 0,05) maka $\mathrm{H}_{0}$ ditolak. Hal itu menunjukkan ada pengaruh signifikan pembiayaan bagi hasil terhadap kesehatan finansial.

\footnotetext{
${ }^{27}$ Op.cit. Kuppusamy, Mudiarasan, Ali Salma Saleh, and Ananda Samudhram

${ }^{28}$ Ibid. Hal. 54
} 
Hasil penelitian ini konsisten dengan teori Ligitimasi, pembiayaan bagi hasil yang sesuai dengan prinsip syariah dalam pengelolaan operasional dan usaha perbankan syariah dapat menghilangkan keraguan masyarakat akan kehilangan keistimewaan yang mereka cari dalam layanan perbankan syariah sehingga akan berpengaruh pada keputusan mereka untuk memilih atau terus melanjutkan pemanfaatan jasa yang diberikan oleh bank syariah. Apabila pembiayaan bagi hasil meningkat maka kesehatan finansialnya meningkat karena pembiayaan bagi hasil yang sesuai prinsip syariah merupakan salah satu cara untuk menjaga kepercayaan dari masyarakat untuk tetap memilih Bank Umum Syariah. Penelitian menunjukan hubungan positif antara rasio pembiayaan bagi hasil dengan kesehatan finansial antara lain Asrori(2014) ${ }^{29}$,dan Kupusamy et. al. (2010) ${ }^{30}$ yang berhasil membuktikan pengaruh rasio pembiayaan bagi hasil terhadap kesehatan finansial.

\section{Variabel Pendapatan Islam terhadap Fraud}

Berdasarkan analisis jalur dapat dilihat untuk pengujian variabel pendapatan Islam terhadap fraud diperoleh nilai beta $(\beta)$ sebesar -0,106 dengan $\rho$-value sebesar 0,036. Karena nilai $\rho$-value lebih kecil daripada a $(0,005<0,05)$ maka $\mathrm{H}_{0}$ ditolak. Dengan demikian ada pengaruh signifikan pendapatan Islam terhadap fraud. Berdasarkan perhitungan yang telah dilakukan, kepatuhan dalam bentuk pendapatan Islam yang berpengaruh signifikan negatif terhadap fraud, dapat diartikan bahwa ketika nilai pendapatan Islam tinggi maka jumlah fraud yang terjadi rendah, hal tersebut berarti bank syariah tersebut melakukan kegiatannya sesuai dengan prinsip syariah atau semakin tinggi tingkat kepatuhan bank syariah maka semakin rendah fraud yang terjadi pada bank

\footnotetext{
${ }^{29}$ Op.cit. Kuppusamy, Mudiarasan., Ali Salma Saleh, and Ananda Samudhram

${ }^{30}$ Ibid. hal. 54
} 
tersebut. Ini mengindikasikan bahwa prinsip syariah apabila diterapkan dengan baik dapat mengurangi tingkat terjadinya kecurangan.

Aktivitas pendapatan bank syariah telah dilakukan atau didominasi oleh aktivitas yang sifatnya syariah dan sesuai prinsip Islam akan tetapi masih terdapat kecurangan yang terjadi sehingga aktivitas pendapatan dan investasi yang telah sesuai dengan prinsip syariah tersebut tidak berpengaruh terhadap kecurangan yang terjadi. Selain itu tidak ditemukannya pengaruh mungkin disebabkan keterbatasan data yang ada pada penelitian ini.

\section{Variabel Pembiayaan Bagi Hasil terhadap Fraud}

Berdasarkan analisis jalur dapat dilihat untuk pengujian variabel pembiayaan bagi hasil terhadap Fraud diperoleh nilai beta $(\beta)$ sebesar -0,416 dengan $\rho$-value sebesar 0,016. Karena nilai $\rho$-value lebih kecil daripada a $(0,016<$ $0,05)$ maka $\mathrm{H}_{0}$ ditolak. Dengan demikian ada pengaruh negatif dan signifikan Pembiayaan bagi hasil terhadap fraud. Hal ini menunjukkan bahwa apabila pembagian bagi hasil tinggi maka fraud yang terjadi pada bank syariah rendah, dapat berlaku sebaliknya.

Pembiayaan bagi hasil merupakan pembiayaan berdasarkan prinsip syrariah. Pembiayaan berdasarkan prinsip syariah adalah penyediaan uang atau tagihan yang dipersamakan dengan berdasarkan persetujuan atau kesepakatan antara bank dengan pihak lain yang mewajibkan pihak yang dibiayai untuk mengembalikan uang atau tagihan tersebut setelah jangka waktu tertentu dengan imbalan atau bagi hasil. Menurut Undang-Undang Nomor 10 Tahun 1998, pembiayaan bagi hasil pada perbankan syariah dilakukan melalui akad mudharabah dan musyarakah. Pembiayaan bagi hasil merupakan salah satu komponen penyusun aset pada perbankan syariah.

\section{Variabel Kesehatan Finansial terhadap Fraud}


Berdasarkan analisis jalur dapat dilihat untuk pengujian variabel kesehatan financial terhadap fraud diperoleh nilai beta $(\beta)$ sebesar -0,160 dengan $\rho$-value sebesar 0,003. Karena nilai $\rho$-value lebih kecil daripada a $(0,003<0,05)$ maka $\mathrm{H}_{0}$ ditolak. Dengan demikian ada pengaruh signifikan kesehatan finansial terhadap fraud.

Peraturan Bank Indonesia (PBI) No. 9 Tahun 2007 tentang Sistem Penilaian Tingkat Kesehatan Bank Umum Berdasarkan Prinsip Syariah. Dalam PBI tersebut dijelaskan bahwa Tingkat Kesehatan Bank adalah hasil penilaian kualitatif atas berbagai aspek yang berpengaruh terhadap kondisi atau kinerja suatu Bank atau UUS melalui: (1) Penilaian Kuantitatif dan Penilaian Kualitatif terhadap faktor-faktor permodalan, kualitas aset, rentabilitas, likuiditas, sensitivitas terhadap risiko pasar dan (2) Penilaian Kualitatif terhadap faktor manajemen. Selain itu, dalam PBI tersebut juga dijelaskan faktor finansial adalah salah satu faktor pembentuk tingkat kesehatan bank yang terdiri dari faktor permodalan, kualitas aset, rentabilitas, likuiditas, dan sesitivitas terhadap risiko pasar. Apabila kesehatan finansial semakin baik maka fraud akan semakin menurun.

\section{KESIMPULAN DAN SARAN}

Berdasarkan hasil dari analisis data dan pembahasan maka dapat diambil kesimpulan sebagai berikut:

1. Pendapatan Islam berpengaruh positif dan signifikan terhadap kesehatan financial diperoleh nilai beta $(\beta)$ sebesar 0,083 dengan $\rho$-value sebesar 0,006. Karena nilai $\rho$-value lebih kecil daripada a $(0,006<0,05)$ maka $\mathrm{H}_{0}$ ditolak. Hal itu menunjukkan ada pengaruh signifikan pendapatan Islam terhadap kesehatan finansial.

2. Pembiayaan bagi hasil berpengaruh positif dan signifikan terhadap kesehatan finansial diperoleh nilai beta $(\beta)$ sebesar 0,437 dengan $\rho$-value sebesar 0,011. Karena nilai $\rho$-value lebih kecil daripada a $(0,011<0,05)$ 
maka $\mathrm{H}_{0}$ ditolak. Hal itu menunjukkan ada pengaruh signifikan Pembiayaan bagi hasil terhadap kesehatan finansial.

3. Pendapatan Islam berpengaruh negatif dan signifikan terhadap fraud diperoleh nilai beta $(\beta)$ sebesar $-0,106$ dengan $\rho$-value sebesar 0,036. Karena nilai $\rho$-value lebih kecil daripada a $(0,005<0,05)$ maka $\mathrm{H}_{0}$ ditolak.

4. Pembiayaan bagi hasil berpengaruh negatif dan signifikan terhadap fraud diperoleh nilai beta $(\beta)$ sebesar $-0,416$ dengan $\rho$-value sebesar 0,016. Karena nilai $\rho$-value lebih kecil daripada a $(0,016<0,05)$ maka $\mathrm{H}_{0}$ ditolak.

5. Kesehatan finansial berpengaruh positif dan signifikan terhadap fraud diperoleh nilai beta $(\beta)$ sebesar -0,160 dengan $\rho$-value sebesar 0,003. Karena nilai $\rho$-value lebih kecil daripada a $(0,003<0,05)$ maka $\mathrm{H}_{0}$ ditolak.

Berdasarkan simpulan dalam penelitian ini, maka saran yang dapat diberikan oleh penulis adalah sebagaiberikut:

1. Variabel independen dalam penelitian ini masih belum dapat memberikan kontribusi yang berarti terhadap variabel dependen sehingga disarankan bagi peneliti selanjutnya untuk menambahkan variabel-variabel independen yang secara teoritis berpengaruh terhadap kesehatan finansial BankUmum Syariah di Indonesia. Jika peneliti selanjutnya ingin menambah variabel baru disarankan untuk menggunakan variabel rasio zakat.

2. Periode pengamatan dalam penelitian ini hanya berlangsung selama 5 tahun dari tahun 2011 hingga tahun 2015, dan sampel yang relatif sedikit yaitu sebanyak delapan Bank Umum Syariah. Sehingga penelitian ini belum bisa secara maksimal menggambarkan keadaan yang sebenarnya mengenai faktor-faktor apa saja yang mempengaruhi kesehatan finansial Bank Umum Syariah diIndonesia. Penelitian selanjutnya disarankan untuk menambah jumlah tahun pengamatan, minimal enam tahun atau menambah jumlah sampel dalam penelitian agar lebih bisa menggambarkanfaktor-faktor apa saja yang mempengaruhi kesehatan 
Marheni

finansial Bank Umum Syariah di Indonesia.

3. Penelitian ini hanya menggunakan Bank Umum Syariah saja.Penelitian selanjutnya disarankan menggunkaan industri perbankan syariah lainnya. Seperti: Unit Usaha Syariah (UUS) dan Bank Perkreditan Rakyat Syariah (BPRS) sehingga hasil dapat digeneralisasi untuk semua jenis perbankan syariah dengan tetap memperhatikan ketersediaan data penelitian. 


\section{DAFTAR PUSTAKA}

Anugerah, R. 2014. Peranan Good Corporate Governance Dalam PencegahanFraud.JurnalAkuntansi, 3 (1), pp.101-113.

Arfan, Ikhsan dan Herkulanus Bambang Suprasto. 2008. Teori Akuntansi dan multi Paradigma, Edisi Satu. Jakarta: Graha Ilmu.

Asrori. 2011. Pengungkapan Syari'ah Compliance dan Kepatuhan Bank Syariah Terhadap Prinsip Syariah. Jurnal Dinamika Akuntansi, Vol. 3, No. 1, pp.1-7

Bank Indonesia. 2007. Peraturan Bank Indonesia No. 9/1/PBI/2007 tentang Sistem Penilaian Tingkat Kesehatan Bank Umum Berdasarkan Prinsip Syariah. Jakarta: Bank Indonesia.

Bank Indonesia. 2007. Surat Edaran No. 9/24/DPbS Perihal Sistem Penilaian Tingkat Kesehatan Bank Umum Berdasarkan Prinsip Syariah. Jakarta: Bank Indonesia.

Bank Indonesia. 2014. Statistik Perbankan Syariah di Indonesia hingga 2014. Jakarta: Bank Indonesia.

Falikhatun. 2012. Bank Syariah Di Indonesia: Ketaatan Pada Prinsip Syariah dan Kesehatan Finansial, Vol. 1, No. 1, Hal. 245-254.

Hameed, S., A. Wirman, B. Alrazi, M. Nazli dan S. Pramono. 2004. Alternative Disclosure and Performance Measures for Islamic Bank. www.iium.edu.my diakses tanggal 4 Mei 2017.

In'airat, M. 2015. The Role of Corporate Governance in Fraud Reduction-A Perception Study in the Saudi Arabia Business Environment. Journal of Accounting and Finance, 15 (2), pp. 119.

Jensen, M. C. and Meckling, W. H. 1976. Theory of the Firm: Managerial Behavior, Agency Costs and Ownership Structure. Journal of Financial Economics, 1976, Vol. 3, No. 4, pp. 305-360.

Jumansyah dan Ade Wirman Syafei. 2013. Analisis Penerapan Good Governance Business Syariah dan Pencapaian Maqashid Shariah Bank Syariah di Indonesia. Jurnal Al-Azhar Indonesia Seri Pranata Sosial, Vol . 2, No. 1, Maret

Kuppusamy, Mudiarasan., Ali Salma Saleh, and Ananda Samudhram. 2010. Measurement of Islamic Banks Performance using Shari'a Conformity and 
Profitability Model. International Association for Islamics Economics. Review of Islamic Economics. Vol. 13, No. 2, pp. 35 - 48

Lane, J.E. 2000. The Public Sector - Concepts, Models and Approaches. London: SAGE Publicationshal. 121

Maradita, A. 2014. Karakteristik Good Corporate Governance pada Bank Syariah dan Bank konvensional. Yuridika, 29 (2).

Najib dan Rini. Sharia Compliance. 2016. Islamic Corporate Governance Dan Fraud pada Bank Syariah. Jurnal Akuntansi dan Keuangan Islam Vol. 4, No.2.

Peraturan Bank Indonesia Nomor: 11/ 3 /PBI/2009 Tentang Bank Umum Syariah.

Peraturan Bank Indonesia Nomor: 6/24/PBI/2004 Tentang Bank Umum yang Melaksanakan Kegiatan Usaha Berdasarkan Prinsip Syariah.

Peraturan Bank Indonesia Nomor: 9/1/PBI/2007 Tentang Sistem Penilaian Tingkat Kesehatan Bank Umum Berdasarkan Prinsip Syariah.

Peraturan Bank Indonesia Nomor: 11/33/PBI/2009 tentang Pelaksanaan GCG Bagi BUS dan UUS.

Rini, R. 2014. The effect of audit committee role and sharia supervisory board role on financial reporting quality at Islamic banks in Indonesia. Journal of Economics, Business \& Accountancy Ventura, 17 (1), pp. 145-156.

Setiawan, Azis Budi. 2009. Kesehatan Finansial dan Kinerja Sosial Bank Umum Syariah di Indonesia. Seminar Ilmiah: Kerjasama Magister Sains Keuangan: Universitas Paramadhina, Ikatan Ahli Ekonomi Islam (IAEI) Pusat, dan Masyarakat Ekonomi Syariah (MES).

Sudiyatno, Banmbang. 2013. Faktor-Faktor yang Mempengaruhi Kinerja Bank (Studi Empiris Pada Industri Perbankan Di Bursa Efek Indonesia). Jurnal Bisnis dan Ekonomi (JBE),Vol. 20, No. 1, pp.25-39.

Undang - Undang Republik Indonesia Nomor 21 Tahun 2008 Tentang Perbankan Syariah.

Wijaya, Angga Sukma. 2012. Kasus Gadai Emas Perburuk Citra Produk Syariah. https://m.tempo.co/read/news/2012/10/04/087433724/kasusgadaiemas-perburuk-citra-produk-syariah. Diakses tanggal 1 Mei 2017. 